\title{
15. 電極表面科学研究懇談会
}

\section{1 設 立}

電極の触媒機能や電極界面における電子移動過程は,電極表面のミク口構造, 電極表面における反応種間相互作用，反応種と電極との相互作用，電極界面の 電場の強さなどによって著しく変化することが知られている。分光学的手法を 用いた溶液/電極界面のミク口構造の解析を試みた研究の歴史は古く, 1931 年 にエリプソメトリーによる鉄の不動態皮膜に関する研究が発表されている。そ の後，紫外・可視反射スペクトル法による電極界面の研究に至るまでの 30 年余 りの間は電気化学研究の主流はボルタメトリーであった。1970 年代の表面巨大 ラマン (SERS) の発見，さらに，1980 年代に入ると，触媒科学に打ける超高真 空測定技術，撖密に規制された清浄表面の作成技術，各種分光学的測定技術が 溶液/電極界面の in situ および ex situ 研究に積極的に取り入れられ，原子・分 子レベルでの電極表面の制御，キャラクタリゼーション，および，電極界面現 象に関する研究は飛躍的な進歩を遂げた。我が国の電気化学者も優れた業績を 挙げ，国際的に大きな貢献をしている。

このような背景の下に，(1) 原子・分子レベルで笅密に制御された電極表面の 構築，(2) IR. UV-vis，SERS，エリプソメトリー法などの各種反射分光法によ る電極界面現象の in situ 研究，(3) 原子レベルで制御された単結晶電極表面に おける電気化学反応の研究, (4) AES, ESCA (XPS), EXAFS, LEED, EELS, Mössbauerによる電極表面の in situ および ex situ研究，(5) 走査トンネル顕 微鏡による電極表面の in situ 研究，(6) これらの研究に関連する機器の開発な どに関する研究活動の推進，情報交換，啓蒙を目的として，板谷謹悟氏（東北 大工)，魚崎浩平氏 (北大理) ほかの有志と相計り，平成 4 年 (1992 年) 4 月に 本研究膯談会を発足させた。

\section{2 活 動}


研究留談会の設置活動の一環として, 平成 3 年電気化学協会春季大会より平 成 4 年春季大会まで 3 回にわたりこの分野で活発に研究活動を続けている研究 者による“分子・原子レベルでの電極表面のダイナミクス”に関するシンポジ ウムを開催した。平成 4 年 4 月 1 日に電極表面科学研究懇談会の設置が認めら れたので, 電気化学協会の春季・秋季大会には定期的にシンポジウムが開催さ れることになった。平成 4 年春季大会では渡辺 正，魚崎浩平，藤平正道，およ び岩沢康裕の各氏による特別セッション，また，平成 4 年秋季大会のシンポジ ウムでは喜多英明, および垣内 隆の両氏による特別講演および 17 件の一般講 演が行われた。

平成 4 年 9 月に第 1 回運営委員会を開催し，事務局に板谷謹悟氏 (東北大工) を，ほか 11 名の幹事を選出した。現在の会員数は個人 53 名，法人 3 社である。

\section{(仁木 克己)}

\section{6. 技術・教育研究懇談会}

\section{1 設 立}

本協会の専門委員会あるいは研究懇談会は，専門細目分野を対象とし，学問 的立場から当該専門分野における情報連絡，研究活動を活性化することを目的 としている。これに対し, 技術・教育研究懇談会は, 電気化学, 工業物理化学, 物質・材料等，本協会関連分野の固有技術ならびに技術教育に関する研究を評 価し促進するために設置された，いわば専門細目分野を横断的に捉えた新しい 懇談会である（主查：春山志郎)。

\section{2 活 動}

本媳談会による第一回技術・教育シンポジウムは, 発会式を兼ねて平成 4 年 (1992 年) 電気化学協会第 57 回大会の一環として開催され, 以後春秋大会に併 せて開催されている。同シンポジウムで発表される論文は，いずれも事前に本 